\title{
Cultural Impact within the Bilateral Cooperation between China and Gabon
}

\author{
Ledaga Néhémie Sabrina \\ Central China Normal University (CCNU), Wuhan, China \\ Email: nledaga@yahoo.fr
}

How to cite this paper: Sabrina, L. N. (2019). Cultural Impact within the Bilateral Cooperation between China and Gabon. Open Journal of Political Science, 9, 599-609. https://doi.org/10.4236/ojps.2019.94036

Received: August 12, 2019

Accepted: September 17, 2019

Published: September 20, 2019

Copyright ( 2019 by author(s) and Scientific Research Publishing Inc. This work is licensed under the Creative Commons Attribution International License (CC BY 4.0).

http://creativecommons.org/licenses/by/4.0/

\begin{abstract}
In an increasingly competitive world where only organized, strong and competitive industries survive, Africa must take advantage of a sector that is naturally natural to it: the cultural sector (Kanel, 2012). The importance of this area is no longer demonstrated because the culture is today at the center of all development. In the same way, faced with the globalization of ever-growing exchanges, it is essential to be culturally well rooted to exchange and compete with other countries. Cooperation between the People's Republic of China and Gabon has progressed over time and has been diversified in several sectors of activity. Thus, this article deals mainly with the question of the impact of culture within the bilateral cooperation between China and Gabon. It also proposes likely strategies to help improve their cultural collaboration in the future. The methods of documentary and qualitative research were used to carry out this analysis.
\end{abstract}

\section{Keywords}

Cultural Impact, Bilateral Cooperation, Trade, China-Gabon

\section{Introduction}

East Asian country, the People's Republic of China has unquestionably become the second-largest economy in the world behind the United States. This spectacular growth (GDP growth rates have often exceeded $10 \%$ per year) is essentially based on the export of consumer goods. The "trading nation" is not just economic power, but also a financial, military and cultural power (Haski, 2013). Also, because of the abundant and cheap availability of its skilled workforce, it has been dubbed "the workshop of the world".

A country located in the center of Africa, Gabon is covered with $85 \%$ of forest or $225,000 \mathrm{~km}^{2}$. Endowed with an advantageous position and strategically on the 
economic plan, it possesses immense wealth with a per capita GDP of 10926 dollars in 2008 (Kanel, 2012). It is classified by the International Monetary Fund as a top-middle-income country, but its economy is based almost entirely on the exploitation of raw materials such as oil, timber, and manganese. Similarly, with the existence of its thirteen national parks, including Lopé, which is a UNESCO World Heritage site, its fauna and flora are still healthy and well preserved.

China's interest in the African continent is an open secret because it considers Africa, particularly Gabon, as a mineral and energy reservoir to exploit. The relations woven between China and Gabon are not new. Their collaboration is evident in many areas of activity. And given the fact that there is always an inequality between the one who brings and the one who receives, the purpose of this article is not to decry the contributions between these two states but to make an exhaustive assessment of this cooperation in matters about forty years later. What contributions or measures have been taken in this area? Who benefits most from their exchanges? And as long as it is considered imperfect, what suggestions it is to make to perfect this cultural cooperation?

\section{Research Methodology}

To carry out this study, the methods of documentary and qualitative research are used. The documentary research method consisted of collecting data via books, theses, dissertations, reports, archives, and other scientific articles directly or indirectly related to this theme. It must be said that this allowed us to better schematize the structure of our work. Qualitative research helped to analyze and critique the data and then make suggestions (Figure 1).

\section{Historical Analysis of Sino-Gabonese Cooperation (1974-2019)}

\subsection{Origin of China-Gabon Diplomatic Links}

The Republic of Gabon gained independence on 17 August 1960 and began its first diplomatic relations with China on 20 April 1974, 14 years after its accession to national sovereignty. The cooperation between China and Gabon is

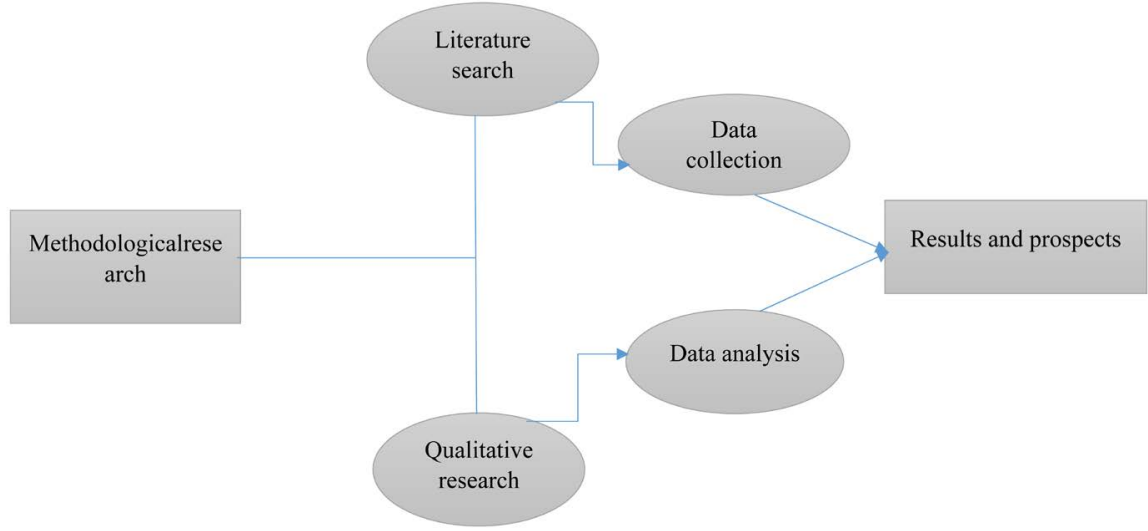

Figure 1. Research methodology. 
mainly part of a particular historical temporality driven by many parameters that affect the economic, social and political dynamics of the country (Banyongen, 2012). Their relations became more and more fruitful and strong because the history of Sino-Gabonese relations is 45 years old today. This date is for both actors a historic event to celebrate annually. Also, politically, China and Gabon have seen their relations grow stronger and stronger. The year 2004 is not the only date of the visit of a Chinese President in Gabon. Indeed, long before that, between 1982 and 1983, he had an African tour marked by the arrival of Chinese reform leaders such as Prime Minister Zhao Liyang who told African leaders of the new direction that would take Chinese support in Africa (Niang, 2018). Since then, leaders and senior officials from both countries have made multiple visits and held regular meetings to discuss cooperation on issues of common interest and international affairs (Sun, 2014). From this history, it is noticed that the collaborative links between the two protagonists have been increasingly profitable and solid over time. A true relationship of friendship and fraternity has developed and the results are very palpable. China has become Gabon's first trade partner in just a few years. Even today, their collaboration is evident in almost all sectors of activity. It cannot, therefore, be spoken of bilateral cultural cooperation between China and Gabon without mentioning the diversity of their exchanges.

\subsection{China-Gabon Trade Diversification}

In addition to the excellent political relations between the two countries, they have also formed very good relationships in several areas of activity. In particular, in terms of economic-technical cooperation and health, the agreement on health was signed on 29 June 1975 in Beijing and renegotiated in 1994 and renewed in August 1996. The agreement on economic and technical cooperation was signed on 6 October 1974 in Beijing and ratified on 2 June 1980. It was subsequently updated in 2006 and 2010 (Gabonese Ministry of Foreign Affairs, 2015). He subsequently had another agreement concerning the large cooperation commission signed on 11 December 1982 in Beijing between the People's Republic of China and the Gabonese Republic. The protocol relating to the application of this agreement came into force on 10 December 1983 in Libreville. It was from this moment that China-Gabon cooperation expanded. Also, the legal framework for their cooperation is very rich. To date, it has nearly 43 agreements, some of which are in force, while others are under negotiation or ratification. According to statistics from the Economic Office of the Chinese Embassy in Gabon, the volume of trade between the two countries reached a record level of 1440 billion francs in 2014. In the first quarter of 2016 on a comparable basis to 2015 , trade increased by $34 \%$ or 1660 billion Francs. In ten years, between 2005 and 2014, the volume of trade has increased sixfold, representing a growth of 600\% (La Rédaction, 2016). And according to the daily Gabon Review, China became Gabon's first trade partner in 2017. In the first half of 2017, this trade 
amounted to 581.2 billion CFA francs; twice as much as last year at the same time. 478 billion CFA francs of goods imported from Gabon, including oil, manganese and sawn timber, were invested by China. A contribution reinforcing the surplus trade balances between Gabon and China (Mouanda, 2017). Currently, China still retains this position as the leading partner of Gabon in trade.

\subsection{Some Achievements of China-Gabon Cooperation}

It is difficult at this time to accurately specify exact amounts and dates for concretization and completion of some of the work. However, it needs to be mentioned some significant facts showing the impact and the place occupied by China in the Gabonese economic landscape (Table 1).

Table 1. Some achievements of China-Gabon bilateral cooperation.

\begin{tabular}{|c|c|c|c|}
\hline $\mathbf{N}^{*}$ & Projects, donations and Chinese achievements in Gabon & Investments & $\begin{array}{l}\text { Year of starting } \\
\text { or finalization }\end{array}$ \\
\hline 1 & Construction of the National Assembly (Palais Léon Mba). & $\begin{array}{l}\text { Estimated at about } \\
25 \text { million US dollars }\end{array}$ & 2000 \\
\hline 2 & $\begin{array}{l}\text { Partial renewal of medical equipment at the Sino-Gabonese Cooperation Hospital in } \\
\text { Libreville and the Sino-Gabonese Friendship Hospital in Franceville (both built by } \\
\text { China in } 1975 \text { and 1988) (Hôpital de la Coopération sino-gabonaise de Libreville, 2016). }\end{array}$ & 3,900,000 yuan RMB & 2002 \\
\hline 3 & $\begin{array}{l}\text { Repair of equipment installed at the Palace of the National Assembly and training of } \\
\text { Gabonese Technicians. }\end{array}$ & $2,800,000$ yuan $\mathrm{RMB}$ & 2002 \\
\hline 4 & Donation of traditional Chinese medicines to the Ministry of Health and Population. & 500,000 yuan RMB & 2004 \\
\hline 5 & Construction of Sénat (Palais Omar Bongo, 2017). & About 20 million US dollars & 2005 \\
\hline 7 & Donation to the Government of Gabon of a batch of antimalarial drugs. & 800,000 yuan $\mathrm{RMB}$ & 2006 \\
\hline 8 & $\begin{array}{l}\text { Construction of Gabonese Radio and Television (RTG) by the China National } \\
\text { Corporation of Import and Export Machinery and Equipment (CEMEC). }\end{array}$ & $\begin{array}{l}\text { Approximately } 3,600,000 \text { us } \\
\text { dollars or } 29,808,000 \text { yuan RMB }\end{array}$ & 2007 \\
\hline 9 & $\begin{array}{l}\text { Fougamou-Mouila Road Construction ( } 35 \mathrm{~km}) \text {, executed by China Communication } \\
\text { Construction Company Ltd. (CCCC) (Gabon-économie, 2016). }\end{array}$ & About 86 billion FCFA & 2009-2014 \\
\hline 10 & $\begin{array}{l}\text { Construction of the roads of Leyou-Lastourville }(97 \mathrm{~km}) \text { and Akiéni-Okondja }(74 \mathrm{~km}) \text {, } \\
\text { executed by the company Sinohydro. }\end{array}$ & $\begin{array}{l}\text { Estimated at about } \\
70 \text { billion FCFA }\end{array}$ & 2009-2014 \\
\hline 11 & $\begin{array}{l}\text { Construction of the Sino-Gabonese Friendship Stadium of Angondjé by Shanghai } \\
\text { Construction. The latter hosted the African Cup of Nations (CAN) in } 2012 \text { (Stade } \\
\text { d'Angondjé, 2011). }\end{array}$ & 30 billion FCFA & 2010-2011 \\
\hline 13 & $\begin{array}{l}\text { Economic and Technical Agreement; interest-free loan granted to the Ministry of } \\
\text { Foreign Affairs. }\end{array}$ & 50 million yuan RMB & 2013 and 2015 \\
\hline 14 & Economic Agreement for the realization of several projects in agriculture. & $\begin{array}{l}50 \text { million yuan RMB or } \\
4,603,239,500 \text { CFA Francs }\end{array}$ & 2016 \\
\hline 15 & $\begin{array}{l}\text { Rehabilitation of the National Assembly after the post-electoral violence of } 2016 \\
\text { (Alix-Ida Mussavu, 2019). }\end{array}$ & $\begin{array}{l}\text { Estimated at } 17 \text { billion CFA } \\
\text { Francs }\end{array}$ & 2019 \\
\hline
\end{tabular}

Source: Gabonese Ministry of Foreign Affairs and other authors. 
This list is not exhaustive; it gives just a glimpse of some existing achievements although others are still in progress. The facts whose figures were the most accessible were favored. All these fields of action show the drive of China to want to perpetuate the principle of "win-win" partnership with Gabon. However, it is not to omit the importance of culture as a source of development. And because of its history marked by several political changes, both Gabon and China have never ceased to reaffirm their commitment to cultural values and principles. What about concrete cultural exchanges between the two protagonists?

\section{China-Gabon Cooperation in Culture}

China and Gabon have shared in the past the same historical fate and form, so to speak, a community of interest, sharing, and fraternity. The bonds that unite them are characterized by fidelity, fraternity, trustworthiness, and sincerity in their mutual collaboration (Sun, 2014). About the state of the art in terms of culture, exchanges have become more and more palpable. They now extend to the education sector. Chinese culture is a source of attraction and in doing so, there is a framework agreement establishing cultural relations between China and Gabon dated May 26, 1984, signed in Libreville; but this one is nonexistent in the archives of the Gabonese Ministry of Foreign Affairs. In terms of cultural visibility emanating from the two-state actors, it is listed as followed:

$>$ The launch of the Sino-Gabonese sewing and floral art training program, on April 13, 2014. This program is jointly run by the National Federation of Women of China and the Union of Women of the Democratic Party of Gabon (UFPDG), of which the aim is to create an opportunity to study the cultures of their respective countries through free and multiple exchanges;

Gabon's participation in international fairs, invited by Chinese companies to set up shop in the "Exhibition and Sales Center for African Products", located in Yiwu, Zhejiang Province, China, to present to international customers more competitive Gabonese products;

D The annual offers of cooperation grants. Alongside this, China also offers advanced courses to Gabonese officials, regardless of department. However, the internship which was carried out annually for the good of the agents of the Ministry of Foreign Affairs became difficult to obtain according to said agents;

The training of Gabonese doctors in China and the granting of scholarships ranging from 4 to 6 years (Gabonese Ministry of Foreign Affairs, 2015).

> Mandarin learning at the Franco-Gabonese Saint Exupéry University (UFGSE) and mainly at the Franco-American Academy of Management (AFRAM), which gives rise to an annual competition called the "Bridge to the Chinese". Pre-selections for this competition were held in Gabon for the first time in 2015 and the winner was awarded a six-month scholarship at the Confucius Institute in Beijing, China.

Opening of the Confucius Institute at Omar Bongo University. This institute 
has been operational since December 2018 and is headed by Wu Chun Feng. This school specializes in learning Mandarin and Chinese culture for all people (Gabon Review).

Finally, as far as culture and the arts are concerned, the Gabonese people love martial arts. It is organized every year in Libreville, the "Great night of martial arts" whose goal is to promote different styles of arts. Shows and demonstrations of Chinese troops are presented. The Gabonese population is also a fan of Chinese Kung Fu and karate films, not forgetting the wearing of the famous "Mao collar" or "Zhongshan costume" for the Chinese.

Here is listed all the cultural realities in terms of cooperation between China and Gabon. The balance that emerges is certainly positive yet it should further expand the exchange knowing well that currently, the cultural field is no longer a negligible sector if not provider of wealth. In our opinion, two plausible hypotheses result. The first is that, given China's multifaceted economic presence in all sectors of activity, it would first focus on other areas of interest to the detriment of this sector of activity. Indeed, one of the main centers of interest of China in Africa, particularly in Gabon is the search for raw materials and energy to exploit. The second hypothesis results from the fact that the Gabonese Government has not yet really realized the economic boom represented by its cultural domain, notably: its cultural tourism (via the beauty, diversity and wealth of its thirteen national parks), the immense wealth of its ancestral rites portrayed through art, sculpture, painting, gastronomy and the economic potential that the Gabonese cultural industries represent today. Cultural industries are now recognized as one of the most dynamic sectors of the global economy. Their annual growth rate for more than twenty years is largely positive and reaches $5 \%$ to $20 \%$ depending on the country. Their weight in the global economy is estimated at more than 7\% according the World Bank in 2003. Although cultural policy efforts have been evident, this sector remains neglected. It is, therefore, necessary to review the definition if not to reinvigorate the establishment of existing cultural policies between the two actors of the international scene so that the disparities of cooperation that exist between the one who brings and the one receives is less or even more equitable for the good of all. Cultural policy refers to a set of conscious and deliberate social practices, interventions or non-interventions designed to meet certain cultural needs through the optimal use of all the material and human resources that a society has at the moment considered (Kanel, 2012). And it has four main functions. Namely: protect the works of the past, that is to say, to safeguard the cultural heritage and restore it to the men of today in all its meanings; stimulate the creation of works that can bear witness to the genius of this time; to ensure the diffusion, that is to say to make accessible to the greatest number the past inheritance and the present creation of the culture; and finally train those who will be responsible for this diffusion (Kanel, 2012).

\section{Cultural Prospects}

Classified by the International Monetary Fund as a top-middle-income country, 
Gabon's economy relies almost exclusively on the exploitation of its raw materials, namely oil, timber, and manganese. Oil plays a leading role in the Gabonese economy. It contributes $40 \%$ of GDP and provides $60 \%$ of state income. However, over the last fifteen years, the volume of production has been declining and, as things stand, reserves should be exhausted for thirty years (Strategic Plan Gabon Emergent, 2012). Similarly, according to some experts, the price of Brent rose from USD 110 to USD 35 per barrel between 2014 and 2016. This decline has shaken all oil and gas producing and consuming countries geopolitically and economically (Niambi, 2018). Gabon is, therefore, thinking of reorienting its investments and diversifying the growth of its economy to reach its goal of emergence set at Prayer 2025. Today, the People's Republic of China has become Gabon's first international economic partner in Gabon several sectors of activity. It is thus the ideal and ideal partner of Gabon to meet the major cultural challenges of adaptation and upgrading that Gabon faces.

Language is an undeniable attribute of a country's soft power and it plays an important role in their relationships. Born in Europe in the last fifteen years of the 20th century, cultural diplomacy, also called soft power, is the concept that designates the modern evolution of so-called "hard power" classical diplomacy, highlighting more cultural than ideological negotiations to avoid the "clash of civilizations". Joseph Samuel Nyerere defined soft power as the ability of a country to expand its power of attraction by using non-coercive tools such as cultural action (Moreau, 2017). In this case, soft power appears as a new form of power on the international scene whose strong cultural presence in a third country such as China, allows a state to positively improve its image, its notoriety by sharing ideologies, values, and also to attract the attractiveness of its culture. It must be said that the power of a state is also evaluated in terms of cultural influence hence the major role that language represents in international trade. Also, linguistic proximity tends to favor trade between countries: having one language in common increases trade flows by about $65 \%$. Attempts to measure the linguistic distance separating two trading partners-from the absence of a common language to perfect linguistic similarity-have shown that the greater this distance, the more the trade decreases (Culture Etudes, 2007). The state of the art in terms of culture allowed us to inquire about the current situation of Gabon vis-à-vis its economic partner China. Although dynamic, the cultural sector within the said cooperation remains minority exploited. When we look at Chinese culture, it can be noticed that what is characteristic of its power lies in its history and its arts: everything is cultural. History because marked by many events, and the arts as symbolic of its cultural heritage, referring here to the culinary arts (known for having therapeutic and dietary virtues), martial arts, sartorial art, ancestral values and traditions, literature, music and intellectual effort in the world ownership of innovative technologies and so on. All these attributes make this country a must-see tourist, commercial and, above all, cultural platform. To this end, we think that it would be wise to review, as a first step, the existing agreement on culture. In consulting the legal framework of China-Gabon 
cooperation, it is seen that this agreement has been signed since the 1980s, namely May 26, 1984, in Libreville. In addition to this agreement, possible cooperation in language should be established. Apart from English which is taught from an early age in primary schools and later on in university, Mandarin now occupies a place of choice in bilateral relations with Gabon. By establishing a China-Gabon language partnership, this would be beneficial both in the means of communication between the various partners and in the education of young elites.

Secondly, additional efforts would be advantages rented to the editions of the Young Caravan $=$ a profession, included in the project of the Gabon Emergent Strategic Plan (PSGE) of the Head of State of the Gabonese Republic, concerning the culture and intellectual effort among youth. Indeed, the Gabonese Government should initiate a policy of basic Mandarin training provided by elites Gabonese or Chinese to provide a supplement to these young people who for the most part have dropped out of school. Also, there are opportunities for them to find employment through Chinese companies located in Gabon. China has been dubbed "the workshop of the world" because of the abundant and less expensive availability of its skilled workforce. This attests that she has been able to invest and give adequate education to her elite to reach this level. Made in Gabon, just as the Made in China is manifest, is possible if the country looks for the means to take advantage of the exchanges with its economic partner, China.

Third, this collaboration would be more fruitful, if both parties could agree to further develop Cultural Tourism. It is defined as the movement of people with essentially cultural motives such as study and cultural trips, artistic tours, trips to festivals or other cultural events, visits to sites and monuments, trips for the discovery of nature, the study of folklore or art, and pilgrimages (World Tourism Organization, 2011). To achieve what it is today, China has had to implement strategies for the Chinese people to love their culture. Namely: "culture for all". This campaign had led to the construction of numerous theaters and stages of shows in rural and urban areas. Why not do the same in this cooperation? The huge cultural-artistic richness that abounds Gabon is dying for lack of substantial infrastructure, the modest financial resources and lack of adequate training to sustain the legacy acquired. Not to mention the piracy that has become legion, the non-respect of intellectual properties and copyrights for all artists and the difficult access to places and cultural tourist sites due to the high cost of establishments and the advanced degradation of roads.

It would not be possible to finish without mentioning the place occupied by the cultural industries in the world and the economic growth of the countries. The observation that we make comparisons in the evolution of the industrialized countries is fundamentally similar. They became aware of their cultural assets to develop their economy. With the arrival of Bollywood for example, we see rhythmic dances steeped in tradition, charm, and belief. A little further, we see Nollywood for Nigeria and the Hollywood giant of the United States, not to mention the New Information Technologies and Communication (NTIC) which 
are constantly developing. Culture is the best ambassador to make his country known to the world. China and Gabon would benefit from setting up framework agreements, favoring or giving access to the Gabonese product such as cinema, music or publishing to name a few, to perfect themselves in contact with Chinese elites. The Middle Kingdom factory is full of all kinds of equipment and advanced materials that can enhance the development of Gabonese cultural industries. The Gabonese state would benefit from having a more strategic vision culturally in the long term and diversify its exchanges with China to better benefit from this privilege.

\section{Conclusion}

China and Africa have tremendous potential for cooperation because they complement each other because Africa is rich in natural and human resources and China has the right techniques and experiences, not to mention their huge respective markets (Geslin, 2004). Africa is perceived by some as being the continent where all the evils are met: famine, poverty, war, insalubrity (Kanel, 2012). It is time for this paradox to cease: a continent with immense wealth and incredible realities of life. Gabon must rise and transform the natural, economic and cultural advantages the country has into a driving force that creates income and well-being for all.

The economic backlog accumulated by Africa particularly Gabon is large but not impossible to fill. We must review the cultural policies put in place and better develop them by thinking more in the long term. We should also review the collective positions and privilege the love of the nation, eradicate these gangrenes that are laziness, corruption, and intellectual piracy to agree to work according to the Gabonese motto: Union-labor-Justice. The one who loves his country works three times more than the one who is just guided by the interest (Niambi, 2018).

It is imperative to invest heavily in the training of young elites just as China has done. Give priority to the long term. Review our educational policies and support young people in their projects. Also, put in place competent human resources and decentralize the different cultural activities to ensure that everyone can reclaim the culture that is the bedrock of the country's identity and our economic growth. Everyone, including the African continent, can be a winner in the globalization of trade provided they have the right assets and the right partners at their side.

It is essential to reinvigorate cultural exchanges between Gabon and China so that the economic balance between the two actors is well taken into account. To be influential and attractive, a country must innovate in the cultural field, strengthening the vitality of the system and guaranteeing all cultural rights and interests (China Research Institute for Reform and Development, 2008). Not so long ago, China was not self-sufficient, but today it is one of the most attractive countries in the world. Its infectious dynamism through the power of its indus- 
try and the wealth of its market are essential and useful assets for the cultural development of Gabon. The data collected throughout this analysis, allowed us to inquire about the insufficiency of cultural actions in the said cooperative although the latter has the merit of having become increasingly strong and diversified. However, aware that this article has certainly not been able to address all the cultural aspects, we hope to have humbly contributed to the development of this cooperation by giving directions of requests for the future and to arouse the interest of other researchers to look into it. Taking into account that China is currently Gabon's first trading partner, an important issue should be on the agenda at future Sino-Gabonese meetings: how to make this bilateral cultural cooperation a profitable cause for Gabon by 2025 ?

\section{Acknowledgements}

I especially thank Professor Wei Hong of Central China Normal University for their advice. I am also grateful to my friend Kathiana Malvoisin, the Drs. Ngomah Le Temps Décide and Niambi T. Nathan for their assistance in my research. Finally thanks to Dienguila Kionga D. and my loved ones for their love and multiform support.

\section{Conflicts of Interest}

The author declares no conflicts of interest regarding the publication of this paper.

\section{References}

Alix-Ida Mussavu (2019). Réhabilitation de l'Assemblée nationale: Ça prend forme. https://www.gabonreview.com/blog/rehabilitation-de-lassemblee-nationale-ca-prend-f orme

Banyongen, E. S. (2012). Economie politique de la coopération entre l'Afrique et la Chine Analyse institutionnelle de la stratégie des acteurs: Les cas du Sénégal et du Gabon (p. 249).

China Research Institute for Reform and Development (2008). 30 Years of Reform in China.Editions in Foreign Languages, Beijing, China.

Coopération Gabon-Chine: Institut Confucius (2018). http://www.gabonreview.com/blog/cooperation-gabon-chine-linstitut-confucis-ouvreses-portes-a-luob

Culture Etudes (2007). Les flux d'échanges internationaux de biens et services culturels: Déterminants et enjeux.

https://www.cairn.info/revue-culture-etudes-2007-2-page-1.htm

Gabon-économie (2016).

http://www.gaboneconomie.net/ge/index.php/dossier/item/1897-532-25-km-de-routes -bitumees

Gabonese Ministry of Foreign Affairs (2015). Gabon-China Cooperation Point. Accessible Document within the Department of Asian and Ocean Affairs.

Geslin, J.-D. (2004). Pourquoi Hu Jintao a choisi le Gabon?

https://www.jeuneafrique.com/123349/archives-thematique/pourquoi-hu-jintao-choisi 
-le-gabon

Haski, P. (2013). La Chine et le Nouvel ordre mondial (p. 14). Rue 89 planètes.

Hôpital de la Coopération sino-gabonaise de Libreville (2016). http://french.china.org.cn/foreign/txt/2016-04/12/content_38225649.htm

Kanel, E.-N. (2012). Le Développement des Industries Culturelles au Gabon (p. 239). Paris: L'Harmattan.

La Rédaction (2016). Direct infos. Les échanges commerciaux entre la Chine et le Gabon. https://directinfosgabon.com/echanges-commerciaux-entre-chine-gabon-ont-augment e-de-34-1er-semestre-2016/

Moreau, N. (2017). La francophonie au service du Soft power-les yeux du monde. https://major-prepa.com/geopolitique/francophonie-service-soft-power-yeux-monde

Mouanda, A. (2017). La Chine premier partenaire du Gabon. https://www.gabonreview.com/blog/commerce-la-chine-premier-partenaire-du-gabon

Niambi, N. T. (2018). Bilateral Cooperation between China and Congo-Brazzaville: The Other Side of the Ledger. Open Journal of Political Science, 8, 227-238. https://doi.org/10.4236/ojps.2018.83016

Niang, I. (2018). Afrique-Chine: Du politique à l'économique, une si longue histoire. https://www.lepoint.fr/economie/afrique-chine-du-politique-a-l-economique-une-si-lo ngue-histoire-22-07-2018-2238157_28.php

Palais Omar Bongo (2017).

http://www.gabonreview.com/blog/palais-omar-bongo-caprices-de-rehabilitation

Stade d'Angondjé (2011).

http://www.worldofstadiums.com/africa/gabon/stade-de-lamitie-sino-gabonaise

Strategic Plan Gabon Emergent (2012). Vision 2025 et orientations stratégiques 2011-2016.

Sun, J. W. (2014). Quarante ans de relations d'amitié et de coopération fructueuses entre la chine et le Gabon. http://ga.china-embassy.org/fra/zxxx/t1148544.htm

Wolrd Tourism Organization (2011). Cultural Tourism.

http://www.culturalamontreal.com/19/Le_tourisme_en_bref.htm\#160 